\title{
APAKAH PROFITABILITAS DAN NILAI BUKU BERDAMPAK TERHADAP RETURN SAHAM?: STUDI EMPIRIS PADA PERUSAHAAN LQ45
}

\author{
Aldi Kurniawan') ${ }^{1)}$ Irdha Yusra ${ }^{2)}$ \\ Sekolah Tinggi Ilmu Ekonomi KBP \\ Email: Kurniawanaldi587@gmail.com \\ Email Pembimbing: irdhayusra@ akbpstie.ac.id
}

\begin{abstract}
At present, there are many options in Indonesia that can be chosen by people who have advantages and one of the investors makes a profit by investing. For investors, the capital market is a place to channel funds in the form of shares, with the hope of regaining high shares. This study aims to discuss the impact of profitability and book value on stock returns. The population in this study is the LQ45 company listed on the Indonesia Stock Exchange (IDX) per period 2013-2017. The sampling technique used a purposive sampling method and based on predetermined criteria obtained a sample of 10 companies. Financial report data is obtained from the official IDX website. The analytical method used is panel data regression analysis with the help of the application E-Views 8. The initial test is done, namely completing the Chow-Test to decide whether the method of Pooled least square or Fixed effect is used; and test the Hausman-test to decide whether the fixed effect method or random effect can be used. The results of this observation state that profitability has a positive and significant effect on stock returns and negative and significant approval book values on stock returns.
\end{abstract}

Keywords: profitability, book value, return

\section{PENDAHULUAN}

Pada saat sekarang ini telah banyak opsi di Indonesia yang dapat dipilih oleh orang yang memiliki kelebihan dananya salah satunya supaya investor memperoleh laba dengan melakukan kegiatan investasi. Investor dapat melakukan investasi dalam berbagai pilihan seperti melakukan investasi di bank ataupun melakukan investasi seperti melakukan pembelian tanah dan emas serta saat sekarang ini pasar modal menjadi tempat berinvestasi. Bagi investor, pasar modal merupakan tempat untuk menyalurkan dananya dalam bentuk berupa saham. Investasi berupa saham memiliki daya tarik tersendiri untuk para investor dimana dengan melakukan investasi saham mereka memiliki harapan agar mendapatkan deviden saham atau pembagian laba yang tinggi. Investor menggunakan pasar modal untuk dapat memperoleh tingkat penghasilan yang tinggi dan juga memiliki risiko yang tinggi terhadap investasi tersebut. Sedangkan untuk perusahaan yang sudah go public untuk mendapatkan tambahan dana, pasar modal menjadi pilihannya agar perusahaan memiliki kemampuan untuk bertahan dan bersaing dengan perusahaan yang lain.

Dengan melakukan investasi di pasar modal maka laba perusahaan dapat meningkat. Menurut Jogiyanto (2000: 12) dalam penelitian (Sutriani, 2014), menjelaskan bahwa kegiatan investasi yang di lakukan dalam pasar modal merupakan kegiatan dengan harapan memperoleh peningkatan dana atau pendapatan atas penanaman modal yang dilakukan dalam bentuk asset dalam 
periode tertentu yang bertujuan agar mendapatkan tingkat hasil investasi yang maksimum sesuai dengan yang mereka kehendaki.

Investor harus memperhatikan mengenai perencanaan yang baik, dengan memperhatikan tingkat risiko dan return yang akan di dapatkan disetiap transaksi agar dapat mempertahankan investasinya. Menurut Jogiyanto (2000: 107) dalam penelitian (Sutriani, 2014) menjelaskan bahwa investor dihadapkan pada risiko ketidakpastian return yang akan di dapatkan, dimana adanya perbedaan antara kenyataan dengan hasil yang diharapkan. Dengan demikian berarti return yang akan diperoleh dikemudian hari masih belum pasti. Return memiliki arti sebagai hasil yang di dapatkan investor dari modal yang ditanamkannya.

Investor juga harus mengetahui selain keuntungan juga tidak dipungkiri mereka juga bisa mendapatkan kerugian atas modal yang ditanamkannya. Kemampuan yang dimiliki investor untuk menganalisis harga saham sangat mempengaruhi laba dan loss yang akan di dapatkan. Return realisasi yaitu return yang sudah berlangsung, agar prestasi perusahaan dapat di ukur maka dihitung berdasarkan data historis (Sutriani, 2014). Untuk menentukan return ekspektasi dan risiko yang akan dihadapi maka digunakan return historis. Return yang memiliki sifat tidak pasti yang diharapkan oleh investor dan terjadi dikemudian hari merupakan pengertian return ekspektasi. Dengan begitu, investor memiliki tantangan yaitu mendapatkan antara profit dengan loss. Yang menjadi konsep return yaitu semakin tinggi tingkat return yang diinginkan maka semakin tinggi pula risiko yang akan diterima dan sebaliknya, berdasarkan konsep return dapat di ambil keputusan bahwa return berpengaruh positif terhadap risiko.

Menurut (Syafri, 2008:304) dalam penelitian (Antara, 2014) Rasio profitabilitas adalah kemampuan yang dimiliki perusahaan dalam menggunakan sumber salah satunya modal, kas, kegiatan penjualan untuk memperoleh profit. Menurut (Riyanto, 2000 dalam Martono, 2009) dalam penelitian (Arista, 2012) Profitabilitas yang tinggi merupakan suatu keberhasilan perusahaan dalam memperoleh laba berdasarkan berdasarkan modal sendiri. Salah satu yang menjadi tujuan utama dari perusahaan adalah untuk mendapatkan profitabilitas dan hal yang penting bagi perusahaan yaitu kemampuan menjaga tingkat profitabilitas. Apabila kinerja perusahaan dapat berjalan secara efisien maka rasio profitabilitas mengalami perkembangan dan peningkatan. Menurut (Yusra, 2016) dalam penelitiannya menyatakan bahwa rasio profitabilitas menunjukkan kemampuan manajemen perusahaan dalam menciptakan keuntungan. ROA adalah salah satu rasio yang dapat digunakan untuk mengetahui dan mengukur kemampuan perusahaan dalam memperoleh earning dengan memanfaatkan semua aktiva yang dimilikinya.

Profitabilitas merupakan ukuran seberapa besar keuntungan yang dapat diperoleh dari modal saham, tingkat penjualan, dan kekayaan (asset) yang dimiliki perusahaan. Profitabilitas yang tinggi merupakan suatu keberhasilan perusahaan dalam memperoleh laba serta menunjukkan kinerja perusahaan yang baik (Rivandi, 2018). Dengan demikian dapat dijelaskan bahwa semakin meningkatnya ROA maka dividen yang diterima oleh pemegang saham akan meningkat (Sutriani, 2014). Menurut signalling theory yaitu suatu kebijakan yang diambil manajemen suatu perusahaan yang dapat memberikan petunjuk bagi para investor mengenai manajemen perusahaan dalam memandang prospek kedepannya. Perusahaan yang 
mempunyai prospek akan memberikan keuntungan sehingga perusahaan akan mencoba menghindari penjualan saham. (Cahyani, 2017).

Berdasarkan uraian diatas dapat ditarik kesimpulan bahwa apabila pemegang saham menerima dividen yang semakin lama semakin tinggi, maka ROAnya juga akan tinggi. Dan ini menunjukkan bahwasanya keahlian perusahaan dalam menjalankan aktiva yang dimiliki untuk menghasilkan keuntungan mempunyai daya tarik dan mampu mempengaruhi investor agar mereka mau membeli surat berharga perusahaan yang berpengaruh pada melonjaknya harga saham. Kesimpulannya adalah return dipengaruhi oleh ROA secara signifikan (Sutriani, 2014). Penelitian yang dilakukan oleh (Antara, 2014) menjelaskan bahwa return dipengaruhi oleh ROA secara signifikan dan positif.

Dari argumentasi di atas, hipotesis pertama yang dapat dibangun adalah sebagai berikut:

\section{H1 $_{1}$ : Profitabilitas berpengaruh positif dan signifikan terhadap return saham.}

Menurut (Ang, 1997) dalam penelitian (Arista, 2012) Agar dapat mengetahui kinerja harga pasar terhadap nilai bukunya maka digunakanlah rasio pasar yaitu price book value $(P B V)$. Rasio ini dihitung dengan membandingkan harga pasar saham dengan nilai buku per lembar saham (book value per share). Book value per share digunakan untuk mengukur nilai shareholder equity atas setiap saham dan dasarnya nilai book value per share dihitung dengan membagi total shareholders equity dengan jumlah saham yang diterbitkan (outstanding shares).

Price to Book Value (PBV) ratio merupakan rasio antara harga pasar saham terhadap nilai bukunya. Rasio ini menyatakan sejauh mana perusahaan bisa menciptakan nilai perusahaan relatif terhadap jumlah modal yang ditanamkannya. Menurut Linda \& Syam (2005) dalam penelitian (Sugiarto, 2011) menyatakan bahwa perusahaan yang dapat beroperasi dengan baik, umumnya memiliki rasio PBV diatas satu, yang menyatakan bahwa book value lebih rendah dari nilai pasar saham. Menurut (Pancawati \& Chariri, 2002) dalam penelitian (Sugiarto, 2011) Semakin tinggi rasio PBV, maka semakin tinggi pula perusahaan dinilai oleh investor yang mana return perusahaan akan berakibat positif. Menurut penelitian (Sugiarto, 2011) menyatakan bahwa rasio PBV perusahaan berpengaruh positif signifikan terhadap return saham.

Dari argumentasi di atas, hipotesis kedua yang dapat dibangun adalah sebagai berikut:

\section{$\mathrm{H}_{2}$ : Nilai buku berpengaruh negatif dan signifikan terhadap return saham.}

\section{METODE PENELITIAN \\ Data dan Sampel}

Penelitian ini dilakukan pada perusahaan yang terdaftar di Bursa Efek Indonesia. Alasan pemilihan obyek ini adalah dalam pemilihan sampel tidak terdapat kendala kekurangan data, dan titik informasi yang pasti mengenai industri yang telah go public.

Sumber data utama dalam penelitian ini adalah Annual Report dan Summary. Jenis data yang didapatkan dari Annual Report dan Summary berupa data 
kuantitatif. Data kuantitatif yang digunakan seperti laporan laba rugi, laporan ekuitas, laporan neraca. Dokumentasi merupakan teknik pengumpulan data dalam penelitian ini.

Populasi dari penelitian ini sebanyak 45 perusahaan, di peroleh dari Perusahaan yang terdaftar pada Bursa Efek Indonesia di akhir periode observasi, yaitu 2017. Metode pemilahan sampel pada pengamatan ini dilakukan dengan metode purposive sampling yaitu metode penarikan sampel dengan penilaian yang berdasarkan pada kategori sesuai dengan objek maupun subjek yang untuk diamati.

Kriteria untuk pengambilan sampel pada pengamatan ini yaitu :

1. Perusahaan LQ45 yang terdaftar di Bursa Efek Indonesia akhir periode Observasi, yaitu Tahun 2017.

2. Perusahaan yang tidak terdaftar secara berturut-turut sebagai saham LQ45 yang terdaftar pada Bursa Efek Indonesia selama periode 2013-2017.

3. Perusahaan terdaftar di Bursa Efek Indonesia sebagai saham LQ45 yang Tidak menerbitkan laporan keuangan selama periode observasi (20132017).

4. Perusahaan yang tidak menyediakan data keuangan sesuai variabel yang diuji yaitu return saham, profitabilitas dan nilai buku.

Berdasarkan kriteria-kriteria tersebut, maka diperoleh sampel pada Tabel berikut:

\section{Tabel 1}

Tabulasi Pengambilan Sampel Menggunakan Purposive Sampling

\begin{tabular}{|l|l|c|}
\hline No & \multicolumn{1}{|c|}{ Kriteria } & Jumlah \\
\hline $1 \quad \begin{array}{l}\text { Perusahaan LQ45 yang terdaftar di Bursa Efek } \\
\text { Indonesia akhir periode Observasi, yaitu Tahun 2017. }\end{array}$ & 45 \\
& $\begin{array}{l}\text { Perusahaan yang tidak terdaftar secara berturut-turut } \\
\text { sebagai saham LQ45 yang terdaftar pada Bursa Efek }\end{array}$ & $(21)$ \\
& $\begin{array}{l}\text { Indonesia selama periode 2013-2017. } \\
\text { Perusahaan terdaftar di Bursa Efek Indonesia sebagai } \\
\text { saham LQ45 yang Tidak menerbitkan laporan } \\
\text { keuangan selama periode observasi (2013-2017). }\end{array}$ & $(8)$ \\
& $\begin{array}{l}\text { Perusahaan yang tidak menyediakan data keuangan } \\
\text { sesuai variabel yang diuji yaitu return saham, }\end{array}$ & $(6)$ \\
$\quad$ Profitabilitas dan Nilai buku. & 10 \\
Jumlah sampel akhir. & 50 \\
Jumlah observasi. & \\
Sumber : diolah peneliti, 2018 & \\
\hline
\end{tabular}

\section{Definisi Operasional Variabel}

Dalam penelitian ini terdiri dari dua macam variabel yaitu variabel independent dan dependent. Variabel independent yaitu Profitabilitas $\left(\mathrm{X}_{1}\right)$, Nilai buku $\left(\mathrm{X}_{2}\right)$. Variabel dependent yaitu Return saham (Y). Selanjutnya dapat diuraikan definisi operasionalnya dari pengamatan ini sebagai berikut:

Tabel 2

Definisi Operasional Variabel 


\begin{tabular}{|c|c|c|c|c|}
\hline No & Varibel & Definisi & Pengukuran & Sumber \\
\hline $\mathbf{1}$ & $\begin{array}{l}\text { Return saham } \\
\text { (Y) }\end{array}$ & $\begin{array}{l}\text { Return saham yaitu } \\
\text { perbandingan } \\
\text { antara harga saham } \\
\text { pada tahun ini } \\
\text { dengan harga } \\
\text { saham pada tahun } \\
\text { berikutnya. }\end{array}$ & Rit $=\operatorname{Ln} \frac{P i . t+1}{P i . t}$ & Suad, 1998 \\
\hline 2 & $\begin{array}{l}\text { Profitabilitas } \\
\text { (X1) }\end{array}$ & $\begin{array}{c}\text { Return on asset } \\
\text { adalah } \\
\text { perbandingan } \\
\text { antara laba bersih } \\
\text { setelah pajak } \\
\text { dengan total aktiva }\end{array}$ & $\begin{array}{c}\begin{array}{c}\text { Return On } \\
\text { Asset }= \\
\text { Laba bersih setelah pajak }\end{array} \\
\frac{\text { Total asset }}{}\end{array}$ & $\begin{array}{c}\text { Cahyani, } \\
2017\end{array}$ \\
\hline 3 & $\begin{array}{l}\text { Nilai buku } \\
\text { (X2) }\end{array}$ & $\begin{array}{c}\text { Price to Book } \\
\text { Value }(P B V) \text { adalah } \\
\text { perbandingan } \\
\text { antara harga } \\
\text { perlembar saham } \\
\text { dengan nilai buku } \\
\text { perlembar saham }\end{array}$ & $\begin{array}{l}\text { Price to Book Value = } \\
\quad \text { Harga perlembar saham } \\
\text { Nilai buku perlembar saham }\end{array}$ & $\begin{array}{c}\text { Wardani, } \\
2011\end{array}$ \\
\hline
\end{tabular}

\section{Teknik Analisis Data}

Dalam penelitian ini dilakukan pengujian hipotesis yang bertujuan menguji pengaruh profitabilitas, nilai buku terhadap return saham. Dalam penelitian ini data yang digunakan yaitu data panel. Data panel merupakan gabungan antara data time series dan cross section (Hadya,Begawati,Yusra 2017). Data sampel sebanyak 10 perusahaan diambil dari data unit cross section dan data time series periode 20132017.

Analisis statistik deskriptif merupakan metode analisis yang digunakan dalam penelitian ini dan menggunakan Program Eviews (Winarno, 2015) untuk analisi regresi data panel. Persamaan regresi data panel yang digunakan dalam penelitian ini adalah:

\section{$\operatorname{RIT}_{\mathrm{it}}=\alpha+\beta_{1}$ PROF $_{\mathrm{it}}+\boldsymbol{\beta}_{2} \mathrm{NB}_{\mathrm{it}}+\varepsilon$}

Dimana RITit merupakan Return Saham pada waktu t, $\alpha$ merupakan konstanta (intercept), $\beta 1, \beta 2$ merupakan Koefisien Regresi, RITit merupakan Profitabilitas perusahaan pada waktu $t$, NBit merupakan Nilai buku perusahaan pada waktu t dan e merupakan Standar error.

Pendekatan yang dilakukan dalam analisis regresi data panel yaitu common effect model (CEM), Fixed effect Model (FEM), random effect model ( REM) (Wulandari, 2017). Ada dua tahapan yang dilakukan untuk menentukan model yang terbaik digunakan antara model tersebut yaitu: Uji Chow, untuk menentukan model mana yang terbaik antara common effect model (CEM) dengan Fixed effect Model (FEM). Uji Hausman, dilakukan untuk menentukan model mana yang terbaik 
digunakan antara Fixed effect Model (FEM) dengan random effect model (REM). Model regresi yang baik harus menghasilkan estimasi linear tidak bias (Best Linear Unbiased Estimator).

HASIL DAN PEMBAHASAN

Uji Statistik Deskriptif Variabel

Tabel 3

Hasil Uji Statistik Deskriptif

\begin{tabular}{lcccc}
\hline \multicolumn{1}{c}{ Variabel } & Minimum & Maksimum & Mean & $\begin{array}{c}\text { Standar } \\
\text { Deviasi }\end{array}$ \\
\hline Return Saham (RIT) & -1.626000 & 1.191000 & 0.012640 & 0.436188 \\
Profitabilitas (PROF) & 2.530000 & 20.68000 & 9.505000 & 4.285432 \\
Nilai Buku (NB) & 0.360000 & 5.610000 & 2.713000 & 1.253217 \\
\hline
\end{tabular}

Sumber : data diolah, Eviews 8

Pada tabel 3 menunjukkan angka-angka deskriptif dari masing-masing variabel dengan jumlah observasi sebanyak 50 (lima puluh). Penjelasan dari analisis deskriptif adalah sebagai berikut :

Return saham merupakan variabel terikat dengan menggunakan return realisasion (Rit) sebagai alat ukur. Nilai minimum sebesar -1.62 berarti perusahaan lebih sedikit membagikan dividen atas investasi yang dilakukan oleh investor. Adapun perusahaan yang memiliki nilai minimum diperoleh oleh PT. Bukit Asam, Tbk pada tahun 2016. Nilai maximum sebesar 1.19 yang berarti bahwa perusahaan lebih banyak membagikan dividen atas investasi yang dilakukan oleh investor. Nilai maximum diperoleh oleh PT. Adaro Energy, Tbk pada tahun 2015. Nilai ratarata return saham sebesar 0.01. Nilai rata-rata Return saham diatas 0 artinya perusahaan lebih banyak membagikan dividen atas investasi yang dilakukan oleh investor. Nilai standar deviasi return saham sebesar 0.43 yang menunjukkan penyebaran data yang lebih besar karena nilainya lebih tinggi dari nilai rata-rata (mean).

Variabel bebas dari penelitian ini adalah profitabilitas dan return on asset sebagai alat ukurnya. Nilai minimum return on asset sebesar $2.53 \%$ menunjukkan bahwa perusahaan mampu menghasilkan laba dengan memanfaatkan asset oleh PT. Adaro Energy, Tbk pada tahun 2015. Nilai maximum Return On Asset sebesar 20.68\% menunjukkan bahwa perusahaan mampu menghasilkan laba dengan memanfaatkan asset oleh PT. Bukit Asam, Tbk pada tahun 2017. Nilai rata-rata return on asset sebesar $9.50 \%$ menunjukan bahwa perusahaan mampu menghasilkan laba dengan memanfaatkan asset perusahaan. Nilai standar deviasi return on asset sebesar 4.28 yang menunjukkan penyebaran data yang lebih kecil karena nilainya lebih rendah dari nilai rata-rata (mean).

Price to book value adalah alah ukur dari nilai buku dan variabel bebas nya adalah nilai buku. Nilai minimum price to book value sebesar 0.36 menunjukkan harga perlembar saham lebih kecil dibandingkan dengan nilai buku perlembar saham perusahaan diperoleh oleh perusahaan PT. Adaro Energy, Tbk pada tahun 2015. Nilai maximum price to book value sebesar 5.61 menunjukkan harga perlembar saham lebih kecil dibandingkan dengan nilai buku perlembar saham 
perusahaan diperoleh oleh perusahaan PT. Indofood CBP Sukses Makmur, Tbk pada tahun 2016. Nilai rata-rata (mean) price to book value sebesar 2.71 menunjukkan kemampuan perusahaan memperoleh nilai buku dengan membandingkan harga perlembar saham dengan nilai buku perlembar saham. Standar deviasi price to book value sebesar 1.25 yang menunjukkan penyebaran data lebih kecil karena nilainya lebih rendah dari nilai rata-rata (mean).

\section{Pemilihan Regresi Data Panel}

Dalam data panel untuk pemilihan model yang terbaik dilakukan tahap analisis dengan cara melakukan estimasi model Common Effect (CEM), Fixed Effect (FEM), dan Random Effect (REM). Persamaan regresi likuiditas dengan menggunakan proksi current ratio adalah sebagai berikut:

$$
\text { RITit }=\alpha+\beta 1 \log P \text { ROFit }+\beta 2 \operatorname{LogNBit}+\varepsilon
$$

Persamaan ini menggunakan transformasi logaritma dalam menentukan model yang terbaik. Hasil statistik yang diperoleh dalam pengestimasian model CEM, FEM, dan REM adalah sebagai berikut:

Tabel 4

Tabel Estimasi CEM, FEM, dan REM

\begin{tabular}{ccccccc}
\hline \multirow{2}{*}{ Variabel } & \multicolumn{2}{c}{ Common Effect } & \multicolumn{2}{c}{ Fixed Effect } & \multicolumn{2}{c}{ Random Effect } \\
\cline { 2 - 7 } & t-statistik & prob & t-statistik & prob & t-statistik & prob \\
\hline \multirow{2}{*}{ PROF } & 1.319532 & 0.1934 & 3.0048 & 0.0047 & 1.5720 & 0.1227 \\
NB & -2.487625 & 0.0165 & -5.8398 & 0.0000 & -2.9636 & 0.0048 \\
\hline
\end{tabular}

Tabel 4 menunjukkan hasil estimasi menjelaskan bahwa masing-masing model memiliki nilai signifikansi yang berbeda-beda. Untuk menemukan model mana yang terbaik maka dilakukan analisis lebih lanjut dengan menggunakan Uji Chow dan Hausman Test.

Tabel 5

Uji chow

\begin{tabular}{lrrr}
\hline Effects Test & Statistic & d.f. & Prob. \\
\hline \hline Cross-section F & 3.189876 & $(9,38)$ & 0.0057 \\
Cross-section Chi-square & 28.137601 & 9 & 0.0009 \\
\hline
\end{tabular}

Uji chow bertujuan untuk menentukan model yang lebih baik digunakan antara model Common Effect dan Fixed Effect. Berdasarkan tabel di atas diperoleh nilai prob pada Cross-section Chi-square lebih kecil dari alpha $(\alpha)(0.0000<0.05)$, maka H0 ditolak. Artinya model Fixed Effect lebih baik digunakan dari model Common Effect. 


\begin{tabular}{lrrr}
\hline Test Summary & $\begin{array}{r}\text { Chi-Sq. } \\
\text { Statistic }\end{array}$ & Chi-Sq. d.f. & Prob. \\
\hline \hline Cross-section random & 25.355103 & 2 & 0.0000 \\
\hline
\end{tabular}

Uji Hausman bertujuan untuk menentukan model yang lebih baik antara model Fixed Effect dan model Random Effect. Tabel 6 menunjukkan bahwa nilai prob pada Cross-section random lebih besar dari alpha $(\alpha)(0.0000>0.05)$. Dengan demikian, disimpulkan bahwa model yang cocok digunakan dalam regresi data panel adalah Fixed Effect Model (FEM).

\section{Uji Asumsi Klasik}

Hasil uji normalitas dengan uji statistik Jarque-Bera tergambar pada grafik berikut:

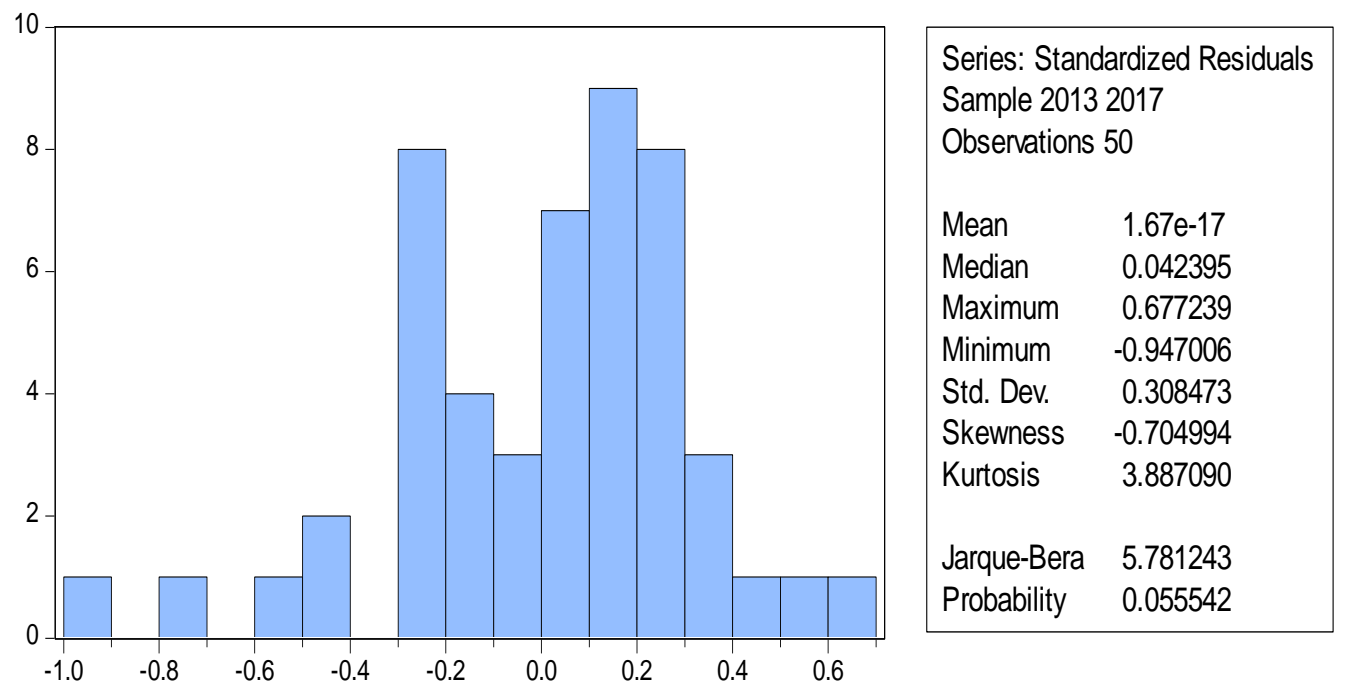

Sumber :data diolah, Eviews 8

\section{Gambar 1}

Hasil Uji Normalitas

Berdasarkan gambar 1 di atas, hasil estimasi profitabilitas yang menggunakan indikator return on asset dan nilai buku menggunakan indikator price to book value terhadap return saham didapatkan hasil uji Jarque-Berra mempunyai nilai sebesar 5.781 dengan probability 0.055 . Nilai probability lebih besar dari alpha $(0.055>0.05)$ maka dapat dikatakan bahwa residual dalam model penelitian ini telah berdistribusi normal.

\section{Analisis Regresi Data Panel}

Dalam penelitian ini teknik analisis data digunakan untuk mengolah, membahas sampel yang sudah diperoleh dan untuk menilai hipotesis yang diduga. Variabel C merupakan constant (konstan), Return saham merupakan variabel terikat (Y), Profitabilitas merupakan variabel bebas $\left(\mathrm{X}_{1}\right)$ dan Nilai buku merupakan variabel bebas $\left(\mathrm{X}_{2}\right)$.

Tabel 7

Tabel Hasil Estimasi Regresi Data Panel 


\begin{tabular}{crrrr}
\hline Variable & Coefficient & Std. Error & t-Statistic & Prob. \\
\hline C & & & & \\
ROA & -0.207915 & 0.411518 & -0.505239 & 0.6163 \\
PBV & 0.680108 & 0.226339 & 3.004826 & 0.0047 \\
\hline
\end{tabular}

Sumber: data diolah, Eviews 8

Persamaan regresi data panel fixed effect model adalah sebagai berikut:

$$
\text { RIT }=-0.2079+0.6801 \text { PROFit }-1.4209 \mathrm{NBit}
$$

Angka pada persamaan regresi data panel didapatkan dari nilai coefficient variabel. Nilai konstanta sebesar -0.2079 ini menjelaskan jika diasumsikan nilai variabel independen bernilai 0 (tidak ada), maka nilai return saham bernilai tetap sebesar -0.2079 .

Koefisien profitabilitas (return on asset) sebesar 0.6801 artinya setiap peningkatan variabel profitabilitas sebanyak 1 satuan berarti akan meningkatkan variabel return saham sebanyak 0.6801 serta beranggapan variabel lain dalam bentuk konstan. Koefisien nilai buku sebesar -1.4209 artinya setiap peningkatan variabel nilai Buku sebanyak 1 satuan berarti akan menurunkan variabel return saham sebanyak -1.4209 serta beranggapan variabel lain dalam bentuk konstan.

\section{Hasil Pengujian Hipotesis}

Tabel 8

Hasil Uji Hipotesis

\begin{tabular}{cccccc}
\hline Variabel & t-statistik & t-tabel & Prob & Alpha & Kesimpulan \\
\hline $\begin{array}{c}\text { Profitabilitas } \\
\text { (PROF) }\end{array}$ & 3.0048 & 1.9844 & 0.0047 & 0.05 & H1 Diterima \\
Nilai Buku (NB) & -5.8399 & 1.9844 & 0.0000 & 0.05 & H2 Diterima \\
\hline
\end{tabular}

Pada tabel 8 untuk variabel profitabilitas dengan menggunakan indikator return on asset secara absolut menunjukkan nilai Thitung lebih besar dari Ttabel (3.0048>1.9844) atau probability lebih kecil dari alpha $(0.0000<0.05)$ maka Hipotesis pertama $\left(\mathrm{H}_{1}\right)$ dalam penelitian diterima. Hal ini berarti bahwa profitabilitas berpengaruh dan signifikan terhadap Return saham.

Untuk variabel nilai buku secara absolut menunjukkan nilai Thitung lebih kecil dari Ttabel $(-5.8399<1.9844)$ atau probability lebih kecil dari alpha $(0.0000>0.05)$ maka Hipotesis kedua $\left(\mathrm{H}_{2}\right)$ terima. Maka disimpulkan bahwa nilai buku berpengaruh negatif dan signifikan terhadap Return saham.

\section{PEMBAHASAN}

\section{Pengaruh Profitabilitas Terhadap Return Saham}

Dari hasil estimasi dengan menggunakan program eviews 8 dapat disimpulkan bahwa profitabilitas sebagai hipotesis $1\left(\mathrm{H}_{1}\right)$ yang menyatakan bahwa profitabilitas berpengaruh positif dan signifikan terhadap return saham, semakin tinggi profitabilitas perusahaan, maka semakin tinggi retun saham yang akan dibagikan kepada investor dalam bentuk dividen. 
Profitabilitas merupakan ukuran seberapa besar keuntungan yang dapat diperoleh dari modal saham, tingkat penjualan, dan kekayaan (asset) yang dimiliki perusahaan. Profitabilitas yang tinggi merupakan suatu keberhasilan perusahaan dalam memperoleh laba serta menunjukkan kinerja perusahaan yang baik. Dengan demikian dapat dijelaskan bahwa semakin meningkatnya ROA maka dividen yang diterima oleh pemegang saham akan meningkat. Menurut signalling theory yaitu suatu kebijakan yang diambil manajemen suatu perusahaan yang dapat memberikan petunjuk bagi para investor mengenai manajemen perusahaan dalam memandang prospek kedepannya. Perusahaan yang mempunyai prospek akan memberikan keuntungan sehingga perusahaan akan mencoba menghindari penjualan saham. (Cahyani, 2017).

Hasil dari penelitian ini konsisten dengan penelitian yang dilakukan oleh (Sutriani, 2014) Dengan demikian dapat dijelaskan bahwa semakin meningkatnya return on asset maka dividen yang diterima oleh pemegang saham akan meningkat atau return on asset secara parsial memiliki pengaruh positif dan signifikan terhadap return saham. Menurut pendapat (Ulupui, 2017) Variabel return on asset berpengaruh positif dan signifikan terhadap return saham.

\section{Pengaruh Nilai Buku Terhadap Return Saham}

Hasil uji nilai t hitung untuk variabel nilai buku membuktikan bahwa $\mathrm{H}_{2}$ diterima artinya ada pengaruh yang signifikan antara nilai buku terhadap return saham. Semakin tinggi nilai buku, maka semakin menurunkan return saham yang yang dibagikan perusahaan dengan investor dalam bentuk dividen. Perusahaan yang memiliki nilai buku yang tinggi maka cenderung return sahamnya lebih rendah.

Price to Book Value $(P B V)$ ratio merupakan rasio antara harga pasar saham terhadap nilai bukunya. Rasio ini menunjukkan seberapa jauh sebuah perusahaan mampu menciptakan nilai perusahaan relatif terhadap jumlah modal yang diinvestasikan. Semakin tinggi rasio Price to Book Value, maka semakin tinggi pula perusahaan dinilai oleh investor yang berakibat return saham akan tinggi pula. Menurut (Pancawati \& Chariri, 2002) dalam penelitian (Sugiarto, 2011). Menurut signalling theory yaitu suatu kebijakan yang diambil manajemen suatu perusahaan yang dapat memberikan petunjuk bagi para investor mengenai manajemen perusahaan dalam memandang prospek kedepannya. Perusahaan yang mempunyai prospek akan memberikan keuntungan sehingga perusahaan akan mencoba menghindari penjualan saham. (Cahyani, 2017).

Penelitian ini konsisten dengan penelitian yang dilakukan oleh (Sugiarto, 2011) mengatakan bahwa Price to Book Value berpengaruh signifikan terhadap variabel dependen yaitu return saham. Menurut (Pancawati \& Chariri, 2002) dalam penelitian (Sugiarto, 2011) Semakin tinggi rasio Price to Book Value, maka semakin tinggi pula perusahaan dinilai oleh investor yang berakibat positif pada return perusahaan. Menurut (Pancawati \& Chariri, 2002) dalam penelitian (Sugiarto, 2011) Semakin tinggi rasio Price to Book Value, maka semakin tinggi pula perusahaan dinilai oleh investor yang mana return perusahaan akan berakibat positif.

\section{SIMPULAN}


Hasil dari penelitian pengaruh Profitabilitas (PROF) dan Nilai Buku (NB) terhadap Return Saham (RIT) dapat disimpulkan sebagai berikut :

1. Profitabilitas (PROF) berpengaruh positif dan signifikan terhadap return saham pada perusahaan yang terdaftar di Bursa Efek Indonesia periode 2013-2017. Artinya, Perusahaan yang memiliki tingkat profitabilitas yang tinggi maka return saham akan tinggi juga.

2. Nilai Buku (NB) berpengaruh negative dan signifikan terhadap return saham pada perusahaan yang terdaftar di Bursa Efek Indonesia periode 2013-2017. Artinya, Perusahaan yang memiliki tingkat nilai buku yang tinggi maka return saham akan semakin tinggi.

\section{UCAPAN TERIMA KASIH}

Selesainya penulisan ini tidak lepas dari bimbingan, bantuan dan dukungan yang sangat berarti dari berbagai pihak. Maka dalam kesempatan ini, penulis ingin menyampaikan ungkapan terima kasih yang sebesar - besarnya kepada :

1. Bapak Febryandhie Ananda, SE, Msi. selaku ketua STIE"KBP” Padang

2. Ibu Febsri Susanti, SEI, MM. selaku ketua Program Studi Manajemen

3. Bapak Irdha Yusra SE, MSc. sebagai dosen pembimbing dalam pembuatan skripsi ini dan penulis banyak berterima kasih atas kesabaran, kepedulian dan kesempatan yang sudah diberikan, penulis berharap kebaikan bapak bisa dibalas oleh Tuhan Yang Maha Esa

4. Seluruh bagian yang sudah banyak menolong penulis yang tidak dapat penulis sampaikan satu persatu.

\section{DAFTAR PUSTAKA}

Antara, S. (2014). Analisis Rasio Likuiditas, Aktifitas dan Profitabilitas Terhadap Return Saham Perusahaan Wholesale yang Terdaftar di Bursa Efek Indonesia. Jurnal EMBA, 2(3), 902-911.

Arista, D. (2012). Analisis Faktor-Faktor yang Mempengaruhi Return Saham (Kasus pada Perusahaan Manufaktur yang Go Public di BEI periode tahun (2005-2009). Jurnal Ilmu Manajemen Dan Akuntansi Terapan, 3, 1-15.

Cahyani, N. I. (2017). Pengaruh Profitabilitas, Likuiditas, Size, Kepemilikan Institutional dan Tangibility Terhadap Struktur Modal. Jurnal Ilmu Dan Riset Akuntansi, 6.

Hadya Rizka, N. B. dan Y. I. (2017). Analisis Efektifitas Pengendalian Biaya, Perputaran Modal Kerja dan Rentabilitas Ekonomi Menggunakan Regresi Data Panel. Jurnal Pundi, 1(3), 153-166.

Rivandi, M. (2018). Pengaruh intellectual capital disclosure, kinerja keuangan, dan kepemilikan manajerial terhadap nilai perusahaan. Jurnal Pundi, 2(1), 41-54. https://doi.org/10.1360/zd-2013-43-6-1064

Suad, H. M. D. (1998). Dasar-dasar Teori Portofolio dan Analisis Sekuritas. (D. Achmadi, Ed.) (3rd ed.). Yogyakarta.

Sugiarto, A. (2011). Analisa Pengaruh Beta, Size Perusahaan, DER dan PBV Ratio Terhadap Return Saham. Jurnal Dinamika Akuntasi, 3(1), 8-14.

Sutriani, A. (2014). Pengaruh Profitabilitas, Leverage, dan Likuiditas TerhadapReturn Saham dengan Nilai Tukar Sebagai Variabel Moderasi pada Saham LQ-45. Journal of Business and Banking, 4(1), 67-80. 
Ulupui, I. G. K. A. (2017). Analisis Pengaruh Rasio Likuiditas, Leverage, Aktivitas dan Profitabilitas Terhadap Return Saham. Jurnal Akuntansi, 4, 1-20.

Wardani, D. K. (2011). Pengaruh Struktur Kepemilikan Terhadap Nilai Perusahaan dengan Kinerja Keuangan dan Kebijakan Hutang Sebagai Variabel Intervening. Jurnal Siasat Bisnis, 15, 27-36.

Winarno, W. W. (2015). Analisis Ekonometrika dan Statistika dengan Eviews (4th ed.). Yokyakarta: UPP STIM YKPN.

Wulandari, N. (2017). Analisis Faktor-Faktor yang Mempengaruhi Inflasi pada Kota Metropolitan di Indonesia dengan Menggunakan Analisis Data Panel. Jurnal Sains Matematika Dan Statistika, 3(2), 34-42.

Yusra, I. (2016). Kemampuan Rasio Likuiditas dan Solvabilitas dalam Memprediksi Laba Perusahaan: Studi Empiris pada Perusahaan Telekomunikasi. Jurnal Benefita, 1(September), 15-23. 